\title{
AN EARLY PROVINCIAL MUSEUM FIELD CAMP IN THE BATTLEFORD AREA
}

\author{
by Margaret Belcher, 2601 Winnipeg Street, Regina
}

In June, 1972 the Saskatchewan Natural History Society will hold its annual field meet in the vicinity of North Battleford and the Battlefords' Provincial Park. Thirty-five years ago the bird life of a part of this area was studied during a six-week period by Fred G. Bard at a field camp established at Cochin by the Provincial Museum (now the Saskatchewan $\mathrm{Mu}$ seum of Natural History). Since then, there have been only occasional reports of the bird life of the Battleford area, and this is now regarded as one of the most neglected corners of Saskatchewan with regard to bird records. An area farther north, from Meadow Lake to Flotten Lake, was studied from July 21 to September 6, 1948 by W. Earl Godfrey's party from the National Museum of Canada (Godfrey, 1950), but this area lies well beyond the Cochin field camp site and, with its mixed-wood forests, represents an ecologically different situation. Some records of observations made in the Battleford area in the 1950's were kept by Spencer G. Sealy when he was a high-school student, and in recent years, a few short trips have been made to the original Cochin study site by Fred Bard and Fred W. Lahrman of the Saskatchewan Museum of Natural History to check the current status of certain colonial bird species. Wayne and Don Renaud spent two and one-half days at the north end of Jackfish Lake June 3-5, 1970, investigating the bird life of the marshes and shoreline.

Mary Houston and I paid a short visit to the Battleford area in 1963 to examine the field-trip possibilities and the availability of accommodation for a future SNHS field meet. We spent the morning of July 27 birding in the provincial park and vicinity, and concluded that it was a good site for a summer meeting. It was then that I approached Fred Bard for further in- formation about his 1935 bird study. He kindly loaned me the bird records that he had copied from his personal diary, and these supplemented the information about Bard's study given in the annual report of the Director of the Provincial Museum (Dunk, 1936).

According to Dunk, the 1935 Museum field camp was located "twenty-four miles north of North Battleford near Jackfish Lake, along the creek which connects Murray and Jackfish Lakes." From the observations recorded, it appears that the district worked from the camp extended south from Cochin to the junction of the Battle and North Saskatchewan rivers, and 20 miles north of Cochin to Glaslyn. The present Highway No. 4, running south from Glaslyn to North Battleford and crossing the river to Battleford, may therefore be thought of as the axis of the study area, with the camp at Cochin as its focal point (Figure 1).

Lying just below the northern limit of the transition zone, in rolling aspen parkland, this area was recommended as a field camp site by Robert $D$. Symons, then a field officer of the Department of Natural Resources stationed at Meota. Symons was struck by the occurrence of certain species of birds regarded at that time as rare in Saskatchewan, and by the generally rich wildlife of this varied habitat with its lakes, streams and excellent marshes. One of the most productive of the marshes referred to in Bard's field notes was "Lamotte's Swamp", ten miles north of the Battlefords' Provincial Park. This was a swamp on crown land leased to M. Lamotte, whose ranch was close by, and it was later gazetted as a bird sanctuary through the efforts of Fred Bard and Bob Symons, and given the title "Marais des oiseaux" as a compliment to the French-Canadian settlers of the area. Unfortunately protection is no longer accorded this valuable marsh. 
they shared the frugal camp fare, they would often see the caravans of impoverished farmers from drought-stricken southern Saskatchewan moving northward in search of new homes.

Many specimens were taken in 1935 , since collecting was a primary function of the field camp. These now form part of the collection of study skins, nests and eggs in the Saskatchewan Museum of Natural History or have been used in preparing exhibits. Specimens were not always recorded in Bard's field notes, but there are accession records for them in the Saskatchewan Museum of Natural History. Bard's principal purpose in keeping a $\log$ book was to note things of special interest, to establish what species were in the area, and to be able to draw conclusions about the breeding status of birds whose nesting range was then unknown. Thus no attempt was made to keep a complete daily list of all birds seen, or to see as many birds as possible each day. Moreover field trips were usually made on foot, owing to the limited gasoline allowance for the car, and no suitable boat was provided for exploration of the lakes. These factors restricted the amount of ground that could be covered daily, as well as the total number of areas that could be visited. So a common resident species like Brewer's Blackbird might not be seen at all for some days, and then seen in numbers on a day when a farmstead was visited. At the camp site at the mouth of the creek surprisingly few migrant waders were seen, although many kinds of shorebirds move through Saskatchewan in the last two weeks of May, but only an occasional visit could be paid to the more suitable shoreline of Jackfish Lake near Meota where Fred Bard does recall seeing many waders. It is apparent to anyone now familiar with the birds of central western Saskatchewan that certain species that might have been seen in the area in 1935 , as well as others like the Starling that were not present then, do not appear in Bard's list.

The birds recorded by Fred Bard during the camp period are listed below in the Species List in A.O.U. CheckList order. Information about them comes from Bard's notes, from Dunk's report as Museum Director (1936), and from Godfrey (1950) to whom Fred Bard furnished a list of specimens collected by him at Cochin. In the case of unusual records, supplementary data have been added for previous and subsequent sightings in the area. Birds believed by Bard to be resident species in the area in 1935 (either or the basis of nests found, or of the presence of birds in numbers, and singing, during the breeding period) are indicated in the list by an asterisk. Additional species established later by other observers as breeding in the area are included in the list in small type.

\section{SPECIES LIST}

*Red-necked Grebe. A few seen May 18,27 , and June 1.

*Horned Grebe. Three pairs seen May 21 , one male June 3 and one female June 4. Two sets of four eggs collected June 10 .

*Eared Grebe. Noted as breeding in the Battleford area (Spencer Sealy, pers. comm., August 8, 1963). Colony of seven nests in marsh at north end of Jackfish Lake noted by Wayne and Don Renaud July 4, 1970 - one nest with five eggs, four nests witth three eggs, two nests with two eggs.

*Western Grebe. A few seen May 19, 21, 24, 27 and June 2, 10. A pair remained near camp in early June. At the mouth of the creek, 22 were seen June 19, 20, fishing as late as 10:00 p.m., ard a number of these were banded.

*Pied-billed Grebe. A few seen May 18, becoming common May 23, 24, 25. Again, a few seen May 27 and June 2. A pair noted near camp.

White Pelican. Seven seen May 19 and two May 25, June 9.

Black-crowned Night Heron. Two immatures seen June 1.

*American Bittern. One seen May 19, two May 21, a few May 25, one June 3 , and a few on June 10.

Whistling Swan. One at Jackfish Narrows, June 9.

Canada Goose. One at mouth of the Battle River, June 7. 
* Mallard. Nests with four and nine eggs May 19, one nest May 21. On June 3 , broods of eight and 10 young were seen, and on June 10 a nest with young.

*Gadwall. A few seen May 18, June 3 and 10.

*Pintail. Two nests with five and nine eggs, May 21. Broods of two and nine June 3. Nest with young, June 10.

*Blue-winged Teal. A few seen May 18, 21, becoming common May 24, 25. A few noted May 27, more common June 2 , a few June 10. Nest with eight eggs June 19.

Cinnamon Teal. One male seen on Murray Lake marsh near Cochin (date not given).

*American Widgeon. Recorded as breeding (no dates given).

*Shoveler. Nest with nine eggs May 19, two nests with seven and nine eggs May 21, a few seen June 3, nest with 10 eggis June 9, common June 10.

*Redhead. One seen May 25, 26, a few June 3, common June 10.

*Canvasback. Common May 19.

* Lesser Scaup. Very common May 21, a few seen May 27, common June 10.

Bufflehead. Two collected May 21, one male collected May 25.

[*Sealy (pers. comm. January 19, 1972) observed the species breeding near Battleford.]

* Ruddy Duck. A few seen May 19, June 1, 3. Nest with eight eggs June 9.

Red-breasted Merganser. One female seen May 23, two females June 4.

*Turkey Vulture. Nesting pair on island south of Murray Lake in 1933 (Symons, 1967).

Red-tailed Hawk. Seen May 18, 21. Nest June 6.

*Swainson's Hawk. On May 19, Bard "saw male with 8 crows and Red-tail standing around." Seen May 21, June $3,6,10$.

"Marsh Hawk. Nest with five eggs at Lamotte's ranch May 21. One female seen May 26. Nests with 4, 4, 5 eggs June 3.

*Sharp-tailed Grouse. Two seen May 21, one June 6 .

"Chukar. Nesting in wild conditions at farm of Mental Hospital, Battleford.
*Gray Partridge. Common May 21, 22, one pair seen May 24, 25, a few May 27, June 2. Nest with 19 eggs June 12, nest with 16 eggs June 14, brood of approximately 20 young June 17. Largest clutch-24 eggs in nest at Battleford on farm of Mental Hospital.

*Sandhill Crane. One see May 19, two May 21. Tracks seen June 3. One rufous-coloured bird June 10. Three years before (1932), R. D. Symons had found what he believes was the last Sandhill Crane nest with eggs at Lamotte's Swamp.

*Sora. A few seen May 21, common May 25 (one collected), a few June 10. Nest with 10 eggs June 20.

*Yellow Rail. Bard's field notes record a number May 19, a few May 21, rails heard again June 3 , and a few June 10. Dunk's report (1936) adds that "a number of slough bottoms where the birds had been heard were dragged over with ropes and nets, but every effort to flush them proved fruitless. Mr. Symons had taken a specimen from this locality after flushing it in this manner." Symons' specimen was collected July 6, 1934 on the Nelson Flats three miles east of Battleford (Bradshaw, 1935; Godfrey, 1950; Symons, 1956, 1967). This was the first specimen in the Provincial Museum, although two previous specimens had been taken elsewhere in Saskatchewan (Houston, 1969). Neither Symons nor Bard was able to locate a nest, although the birds were evidently breeding.

* American Coot. Adult with seven or more young on creek, and nest with one addled egg in marsh at north end Jackfish Lake seen by Wayne and Don Renaud July 3, 1970.

*Killdeer. A few seen May 25, 27, common June 10.

"Common Snipe. Common May 19. Nest with three eggs, June 3 (Dunk's report notes nest with three eggs collected on this date 24 miles northwest of Cochin.)

*Upland Plover. Two noted May 19.

* Spotted Sandpiper. A few seen May 18, one May 22, 24, three May 27, a few June 2, 6 . 


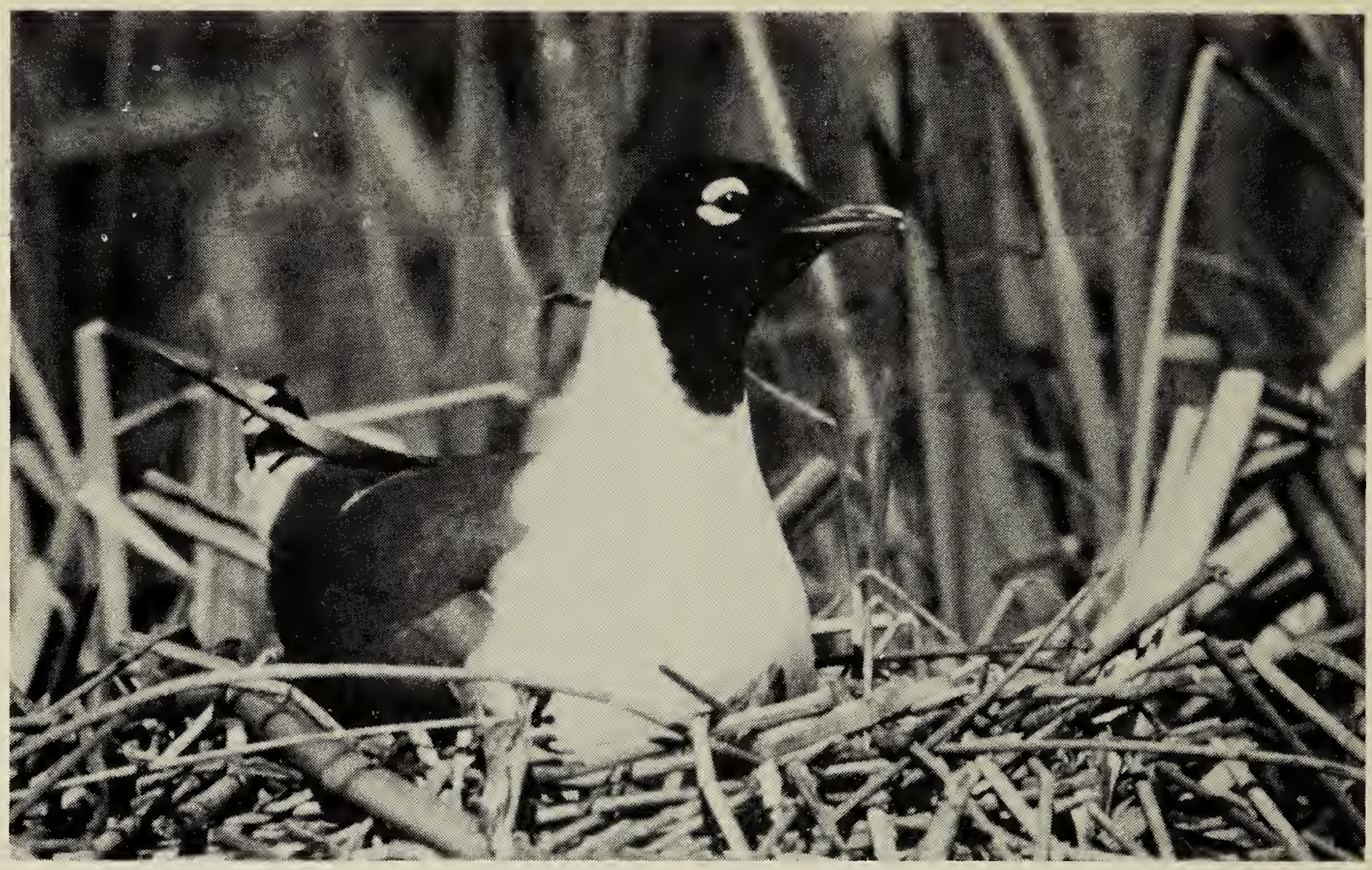

Franklin's Gull at Murray Lake, May 29, 1952.

Photo by Fred W. Lahrman

*Willet. Common May 20, 21. Five seen June 3.

Lesser Yellowlegs. Two seen June 11.

* Marbled Godwit. A few seen May 18, 19, 25, six June 3, a few June 7, 10.

*Wilson's Phalarope. Common May 22, three May 25, 14 June 2. Four nests June 3, with two sets of eggs collected (Godfrey, 1950). Common June 10.

Herring Gull. Two immature males taken at Jackfish Lake, June 17 (Dunk, 1936; Godfrey, 1950). Bard's field notes give date as June 18.

California Gull. Recorded (no date given). Gulls of this species noted by Mary Houston and the writer July 27, 1963.

Ring-billed Gull. A few noted May 27. [*Sealy (pers. comm. January 19, 1972) observed a breeding colony in 1968 on Jackfish Lake.]

*Franklin's Gull. Very common May 19, 20, 21, 27, June 10. Bard recalls "hours" of these gulls drifting by the camp in long, undulating strings-out in the morning, back at night. According to Dunk, the nesting site of a "very large colony of Franklin's Gulls, estimated to contain fifty thousand birds" was visited June 24 on Murray Lake near Cochin. Some of the nests had just been completed; others contained from one to five eggs. Adults, chicks, and nests were collected. This colony was re-visited on May 2930, 1952 by Fred Bard and Fred Lahrman, who estimated that 25,000 Franklin's Gulls were nesting there. Several years later, however, they were $\mathrm{n}_{\mathrm{n}}$ longer nesting on Murray Lake. Wayne and Don Renaud found a nesting colony, estimated to contain over 200 pairs, in the marsh at the north end of Jackfish Lake, July 4, 1970. These were probably birds from the earlier Murray Lake colony, as Franklin's Gulls seem to move about unpredictably.

*Bonaparte's Gull. Five seen May 19, four May 20. Two nests with three eggs in each found June 3 (Godfrey, 1950 , records that one of the nests and three eggs were collected). A few seen June 10. Dunk (1936) notes that Bard visited one nest again June 20 when the last of three young were hatching, and materials were collected for a marsh habitat group (the "Lamotte's Swamp Group-Glaslyn" at SMNH). 
This is the breeding locality described by R. D. Symons in Hours and the birds (1967) and in his account in The Blue Jay of the "Atypical nesting cf Bonaparte's Gull in Saskatchewan" (1968). The first breeding record for Saskatchewan was established by Symons in May, 1932. On May 31, 1933 Symons collected a female bird and took the nest and three eggs for the Provincial Museum.

Bard checked the colony in Lamotte's Swamp again in 1955 and 1956 (Bard, 1956). In July, 1955 he saw one young Bonaparte's Gull flying with adults south of the swamp, and in 1956 he saw five adults and found one nest with three eggs. On June 7, 1969 (not June 17 as erroneously reported in the Blue Jay) Fred W. Lahrman and Lorne Scott of the Saskatchewan Museum of Natural History visited the swamp and found a nest with three eggs. The screaming pair above the nest were joined by a third bird, possibly one of of a second breeding pair, but the gulls were "fewer in numbers than in previous years" (Lahrman, 1969). On June 28, 1970 Lahrman and Scott spent one-half hour at the swamp, and noted a single Bonaparte's Gull aggressively defending territory. No nests were found, but one young Bonaparte's Gull (possibly a week old) was found dead (Lorne Scott, pers. comm. January 18, 1972).

*Forster's Tern: Birds were reported by Bard May 21 (3?), May 23 (one taken), May 24 (3), May 25 (5), May 30 (4), June 2 (3), June 4 (3), June 1:) (heard), June 11.

Dunk (1936) cites Bard's account of the trip made June 11 with R. D. Symons to the marsh south of Murray Lake to seek the nesting site of these terns: "On our arrival at the marsh several were seen in flight, two of which suddenly dropped into the tule reeds. As we paddled towards the spot two Forster's and one Black Tern took flight from a floating mass of old marsh reeds, about fifteen feet long and two feet in width. As we approached two single eggs were seen.
Having brought the canoe alongside the reeds, two hollows were found, one of which contained two eggs, the other one. These eggs were larger and lighter in color than those of the Black Tern, three of which were found in a well-constructed nest on the opposite side of the floating reeds. On our way out of the marsh another Forster's took flight from the top of an old muskrat house. No eggs or nest was found here.

"Wishing to get a nest of the Forster's Iern with the usual three eggs the marsh was visited again on June 12 th, only to find the eggs had probably been destroyed, the crude nests being empty. No broken shells were found. The nest of the Black Tern was found intact.

"We were disappointed at the loss of this our first nesting record. As we were returning, what was evidently a female Forster's Tern was flushed from the muskrat house. Here was found one egg. Photographs were taken, the egg collected and carefully wrapped. One egg from a Black Tern's nest nearby was placed in the 'excuse' for a nest on the rat house. Shortly after the bird was flushed it returncd to the nest. On the next visit this egg had disappeared and the nest was deserted. From this was concluded that the Forster's Terns are very timid when laying and if disturbed at this period desert the nest and destroy the eggs, or the eggs may have been destroyed by non-breeding Franklin's Gulls."

When Fred Bard and Fred Lahrman visited Murray Lake on May 29, 1952 they saw several Forster's Terns.

On the basis of Dunk's report, Gerrard and Whitfield (1971) give this locality as one of two breeding localities of the Forster's Tern in this general area. The second locality was a marsh described as 10 miles north of Meota, where three nests were found on June 3, 1959 by Spencer Sealy (F.N.R.S.).

On a brief visit to Cochin in 1961, Fred Bard and Fred Lahrman failed 


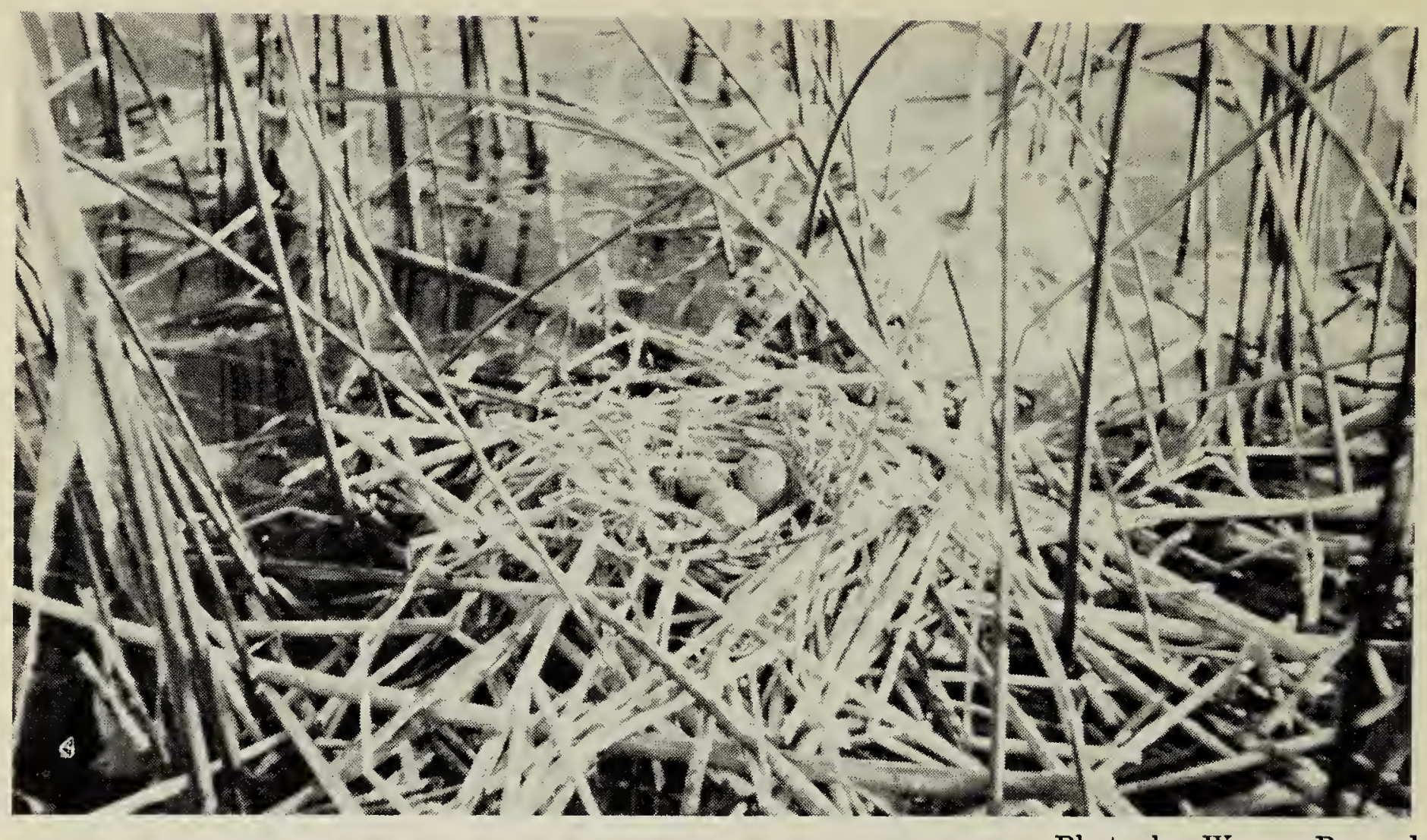

Photo by Wayne Renaud

Nest and eggs of Forster's Tern at the north end of Jackfish Lake.

to note Forster's Terns. However, on July 3 and 4,1971 at the location visited by Sealy in 1959, approximately 37 nests were found by Wayne and Don Renaud in a small, marshy bay of Jackfish Lake about threequarters of a mile south-southwest of Aquadeo Beach. Most of these nests were empty, but some contained eggs or young. The observers searched only a part of what they believed to be the total colony, but judged the number of adult birds present to indicate a colony of between 50 and 100 pairs, which would be one of the largest Forster's Tern colonies in Saskatchewan (Renaud, 1971).

*Common Tern. Common May 18, 24, few May 27. Bard believed they might be nesting on Jackfish Lake, but had no evidence. However, Sealy found them nesting there in 1960 (pers. comm., January 19, 1972), and on July 13, 1963 Stuart and Mary Houston banded 111 on two little islands in the marshy bay at the south end of Jackfish Lake, while more than 20 young swam away unbanded, and 15 nests were left with eggs. On July 25, 1965, the Houstons banded 21 at the same site, but the colony was not thriving, and they learned locally that the terns had been molested by children throwing stones. (C. Stuart Houston, pers. comm., January 16, 1972).

*Black Tern. Common May 18, 21, 25, very common May 27, June 3. Nests of two and four eggs, June 9.

*Mourning Dove. Common May 21, heard May 30, six at Paynton June 6, common June 10.

* Black-billed Cuckoo. Bard believed it to be breeding. Substantiated by Sealy who has a nest record for Battleford (pers. comm., January 19, 1972).

*Great Horned Owl. One seen May 22, June 3, 6.

*Long-eared Owl. One seen May 18.

*Short-eared Owl. One seen at Lamotte's Swamp May 22, one June 6, 10.

*Common Nighthawk. One seen May 29, a few June 2, 3, 6, 10.

* Ruby-throated Hummingbird. One reported flying past camp May 21.

*Yellow-shafted Flicker. Nesting May 19, 27 (two pairs), one female seen May 29, one male May 30, two males May 31. Nesting (common) June 10. 


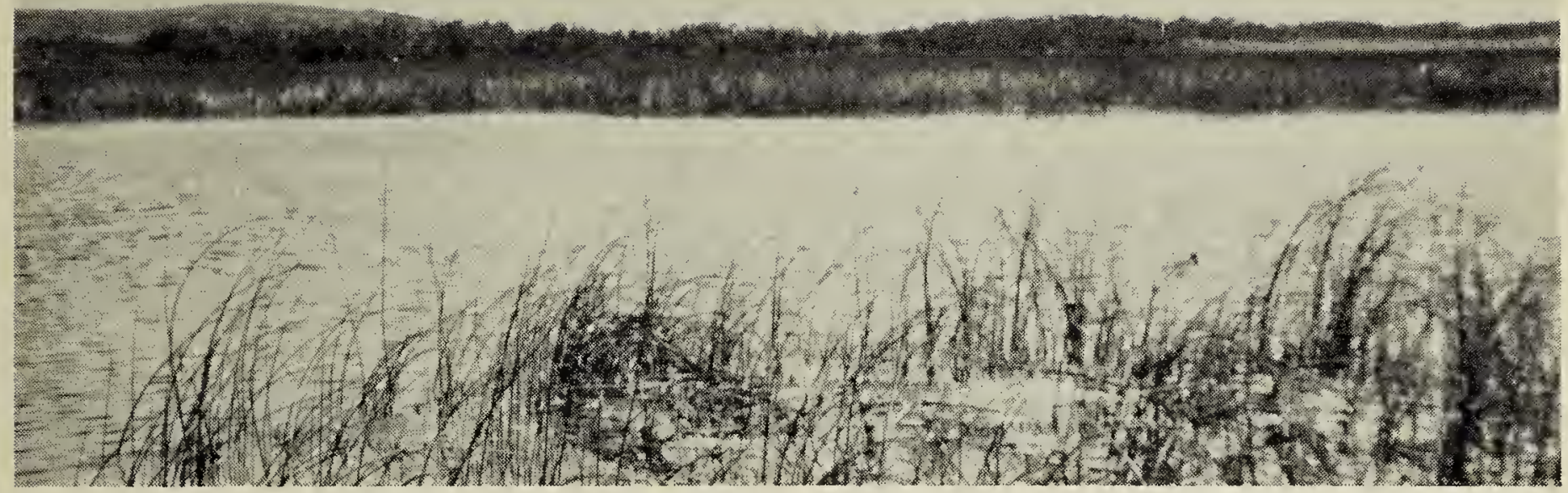

Photo by Wayne Renaud

Marsh habitat near Aquadeo Beach where Black and Forster's Terns and Franklin's Gulls nest in abundance.

*Yellow-bellied Sapsucker. One seen
May 20 .

*Hairy Woodpecker. One male seen May 19. Nesting May 24.

*Downy Woodpecker. Breeds near Battleford according to Sealy (pers. comm., January 19, 1972). One pair seen at the park July 27, 1963 (Belcher, Houston). Nest found in poplar tree in the Battlefords' Provincial Park by Fred Lahrman June 7, 1969.

*Eastern Kingbird. A few seen May 18, 21, 22, becoming common (new migrants) May 24, 26, a few June 2, common June 10.

*Western Kingbird. Breeding at Battleford 1959 (Sealy, pers. comm., January 19, 1972). Nest with four eggs at Aquadeo Beach, July 3, 1970 (Renaud, pers. comm., January 6, 1972.

*Eastern Phoebe. Nesting May 29 (two nests, one being built, one with three young and two eggs-under bridges). Nest with four eggs collected at Cochin, June 14; nest with one egg plus one cowbird egg collected at Iffley June 15 (Godfrey, 1950).

* Least Flycatcher. Three seen May 19, a few May 24, 25, 27, June 2, 6. Two males collected June 6.

\section{*Western Wood Pewee. Heard June 18.}

*Tree Swallow. Common May 18, 24, 25, a few May 27, common June 1, a few June 2, 3, common June 10.

*Bank Swallow. Colony of about 50 burrows noted July 3, 1970 in bank of North Saskatchewan River south of Battleford by Wayne and Don Renaud.
* Barn Swallow. Seen May 21, a few June 3, common June 10.

* Purple Martin. Several pairs noted north of Jackfish Lake and one nest with three halfgrown young found under an eave July 4, 1970 by Wayne and Ron Renaud (pers. comm., January 16, 1972).

*Black-billed Magpie. Common near Battleford when Sealy arrived there in 1958 (pers. comm., January 19, 1972).

*Common Crow. Two nests with three and five eggs May 21, two with three and five eggs May 25, common May 25 , nest with young May 31, nest June 10 (when Bard noted, "few have young, season late.")

*Black-capped Chickadee. Two seen May 25, one Jure 1, nest with young June 11.

*House Wren. A few May 19-25, becoming common June 3, 10.

*Long-billed Marsh Wren. A few seen May 19, 24, 25, June 3, common June 9 , 10. At Murray Lake nearly 100 nests (many of course unoccupied) were found on May 29, 1952 by Fred Bard and Fred Lahrman; two nests were collected that had seven eggs each. Many nests were again found on Murray Lake on Bard's visit in 1961, and three nests were found July 3-4, 1970 by Wayne and Don Renaud at the north end of Jackfish Lake (pers. comm., January 16, 1972).

* Short-billed Marsh Wren. Heard June 1. A few seen June 10. 
*Catbird. No dates given, but Bard commented on varied repertory of imitative calls.

*Brown Thrasher. A few seen May 21, 24, 27, June 2. Nest with four eggs June 9.

*Robin. Nest with three eggs May 19. Common May 27, June 10.

*Veery. A few noted May 21, 24, 25, 27, June 3.

* Mountain Bluebird. Nesting May 21.

*Sprague's Pipit. A few noted May 19, June 3; becoming common June 7, 10. Dunk's comment (1936) is of interest: "This bird of the prairie has evidently extended its range to the wooded country north of Battleford. They were seen twenty-four miles northwest of Cochin in May, 1935. This being their nesting time, they probably breed here."

*Cedar Waxwing. A few heard May 30, June 1, 2, 4; becoming common June 9,10 .

*Loggerhead Shrike. Common May 18, one seen May 25, a few June 3, common June 10.

* Starling. Adults seen with food by woodpecker hole July 3,1970 by Wayne and Don Renaud (pers. comm., January 19. 1972). Have been present since Sealy arrived in Battleford in 1958 (pers. comm., January 19, 1972).

*Red-eyed Vireo. One seen May 29, heard June 4. One male collected June 6. A few noted June 10.

Philadelphia Vireo. Migrant. One seen at Cochin June 9. Dunk (1936) commented "uncommon in the province". Bard's notes described song as "twosyllabled, quite like Red-eyed."

*Warbling Vireo. One seen May 28, a few June 10.

*Tennessee Warbler. Common May 19, a few noted May 25, 27, June 1. Nest with two warbler eggs and two cowbird eggs June 15, reported by Dunk (1936) and Godfrey (1950) as collected.

*Yellow Warbler. Common May 19, 20, 21, 25, June 2, 3. Nest with four eggs June 6 ; a destroyed nest June 9 .

Myrtle Warbler. Common May 19, one seen May 25, common May 28.
Blackpoll Warbler. First migrants: common May 19, a few May 24, 25, 27.

American Redstart. One male seen May 29, June 2. One noted June 6. $[$ *Sealy records it as breeding near Battleford (pers. comm., January 19, 1972).]

* House Sparrow. Noted as comnion breeding species from Sealy's arrival in 1958 (pers. comm., January 19, 1972).

*Bobolink. One male collected in the vicinity of Battleford May 21. Three seen May 22; heard June 3; a few noted June 10.

*Western Meadowlark. Common when listed June 10.

*Yellow - headed Blackbird. Common May 19, 20, 21, 24, 25; very common June 1; common June 10. Common June 16-22 (two nests with two and four eggs, two nests with one and four young).

*Red-winged Blackbird. Nesting May 25. Common May 27. Two nesits with one and four eggs June 3, nesting June 10.

* Baltimore Oriole. One male seen May 18, common May 22, females seen May 25, common May 27 and very common June 2. Nest near camp June 9.

*Brewer's Blackbird. Common when recorded June 14.

* Common Grackle. One male collected May 23. A few seen May 27. Five banded June 3. Common June 10.

*Brown-headed Cowbird. A few seen May 18, becoming common May 24, 27. A few seen June 3.

*Rose-breasted Grosbeak. One male seen May 21. Heard June 2. A few noted June 6. Heard June 9. No nest found, but males were singing and assumed breeding.

Pine Siskin. Five seen May 18.

*American Goldfinch. Several heard and seen July 3-5, 1970 by Wayne and Don Renaud (pers. comm., January 16, 1972). Also seen July 27, 1963 (Belcher, Houston). Assumed by the author to be breeding.

* Rufous-sided Towhee. Three noted along North Saskatchewan River at Battleford June 12, 1971 by Wayne and Don Renaud (pers. comm., January 16, 1972). Assumed by the author to be breeding.

* Savannah Sparrow. A few seen May 19, June 1, 2, 3; becoming common June 10. 
*Baird's Sparrow. Dunk (1936) noted, "The northward movement of prairie birds is again apparent from the number of Baird's Sparrows in the vicinity of Battleford, June, 1935. Evidently they were breeding here."

*Leconte's Sparrow. A few seen May 19, 21; two June 1; a few June 3, and common June 10.

* Sharp-tailed Sparrow. A few seen May 19, 24, 25, June 3; common June 10 .

*Vesper Sparrow. A few May 19, becoming common May 20, 21, 26. A few June 3, common June 10.

*Lark Sparrow. Breeding near Battleford, 1959 and 1960 (Sealy, pers. comm., January 19, 1972).

Tree Sparrow. Common May 27.

*Chipping Sparrow. Common May 19, a few May 24-26.

*Clay-colored Sparrow. Common May 18, 21, 24, 25, 27.

Harris' Sparrow. Heard May 15, one seen May 19.

White - throated Sparrow. Common May 19, 21. One seen May 24. Heard singing June 12, 19 (possibly breeding, but no definite evidence.) Reported by Godfrey (1950) as breeding at Flotten Lake, and "noted south to Glaslyn." Fred Bard and Fred Lahrman tape-recorded a White-throated Sparrow's song on May 22, 1956 near Lamotte's Swamp.

*Lincoln's Sparrow. A few seen May 19. Nest with four young June 20 [sic]. Dunk (1936) gives date as June 10, "first nesting record for the province." Adult female collected June 20 (Godfrey, 1950) at Tamoths [sic]. Since no such place name exists, "Tamoths" may be a misprint for Lamotte's (i.e. Lamotte's Swamp).

* Swamp Sparrow. A few seen May 19, 21. Heard June 3. Common June 10. Breeding.

*Song Snarrow. Common May 19, 25, 27, June 10.

McCown's Longspur. One seen June 3.

\section{Acknowledgments}

I am grateful to Fred G. Bard for lending me some years ago his 1935 bird records from the Provincial
Museum camp at Cochin, and for taking time recently (just before leaving Regina for the winter) to tell me more about the camp activities.

I also wish to acknowledge the useful information given me by Robert D. Symons, who spent considerable time in the study area when he was stationed there as a DNR field officer and accompanied Bard on a number of field trips. Further information about breeding species was helpfully supplied by Fred W. Lahrman, Lorne Scott, C. Stuart Houston, Spencer G. Sealy and Wayne and Don Renaud. Critical commenits on the manuscript were made by Robert W. Nero.

I hope that the renewed interest taken in the Battleford area this year, with the SNHS summer meeting being held there, will lead to the publication of a bird list for the locality.

\section{LITERATURE CITED}

American Ornithologists' Union. 1957. Checklist of North American birds. 5th ed. Lord Baltimore Press, Baltimore, Maryland. 691 pp.

Bard, Fred G. 1956. Bonaparte's Gull. Blue Jay, $14: 80$.

Bradshaw, Fred. 1935. Report of Director, Provincial Museum of Natural Resources for year ending April 30, 1935. In Annual Report of Department of Natural Resources. Govt. of the Prov. of Sask., Regina.

Dunk, F. 1936. Report of the Director, Provincial Museum, Dept. of Natural Resources for year ending April 30, 1936. In Govt. of the Prov. of Sask.. Dept. of Natural Resources, Annual Report for year ending April 30, 1936.

Gerrard, J. M., and D. W. A. Whitfield. 1971. Breeding distribution of Forster's Tern in the Prairie Provinces. Blue Jay, $29: 19-22$.

Godfrey, W. E. 1950. Birds of the Cypress Hills and Flotten Lake regions, Saskatchewan. Bull. No. 120, Nat. Mus., Ottawa. 96 pp.

Lahrman, Fred W. 1969. Bonaparte's Gull nesting at Glaslyn, Saskatchewan. 1969. Blue Jay, $27: 221$.

Houston, C. Stuart. 1969. Nesting records of the Yellow Rail in Saskatchewan. Blue Jay, $27: 81-82$.

Renaud, W., and D. Renaud. 1971. Another Saskatchewan colony of Forster's Tern. Blue Jay, $29: 131$.

Symons, R. D. 1956. Random notes on the Yellow Rail. Blue Jay, 14:8 - 9 .

Symons, R. D. 1967. Hours and the birds. University of Toronto Press, Toronto, 224 pp.

Symons, R. D. 1968. Atypical nesting of the Bonaparte's Gull in Saskatchewan. Blue Jay, $26: 70-74$. 